\title{
An Analysis of a First-Year Class on the Self-Efficacy of University Students in Japan
}

\author{
Kimie Shin ${ }^{1, *} \&$ Masafumi Nakagami ${ }^{2}$ \\ ${ }^{1}$ Education Development \& Learning Support Center, Ritsumeikan Asia Pacific University, Beppu, Japan \\ ${ }^{2}$ College of International Management, Ritsumeikan Asia Pacific University, Beppu, Japan \\ *Correspondence: Education Development \& Learning Support Center, Ritsumeikan Asia Pacific University, Beppu, \\ 974-8577, Japan. Tel: 81-977-78-1111. E-mail: kimishin@apu.ac.jp
}

Received: August 21, $2015 \quad$ Accepted: September 22, $2015 \quad$ Online Published: September 30, 2015

doi:10.5430/jct.v4n2p62

URL: http://dx.doi.org/10.5430/jct.v4n2p62

\begin{abstract}
This study aimed to examine the effect of the first-year class in Japanese universities on developing students' self-efficacy. An analysis of the class design based on the theory of self-efficacy implies that such courses are primarily intended to develop students' self-efficacy by putting them through enactive mastery experiences. In addition, the courses are designed to use intensive cooperative learning to provide vicarious experiences, which act as a mechanism to trigger a synergy effect on students' enactive mastery experiences during the course. The courses were also designed to utilize a social persuasion mechanism to support students engaged in enactive mastery experiences. Statistical analysis reveals that the students in these first-year courses have improved some aspects of self-efficacy during the course period, consistent with the course design.
\end{abstract}

Keywords: first year education; self-efficacy; instructional design

\section{Introduction}

In first-year education in Japan, methods to improve students' self-regulation and proactive attitude are currently being widely implemented (Yamada, 2013). As university education has become more popular, a problem has developed: many students enter university with lack of a "desire to learn," which often leads to difficulties in learning at the university (Kawashima, 2008). To ensure their success, fostering students' proactive and self-regulating attitudes has become a learning goal for first-year education in Japanese universities (Yasunaga, 2012). To pursue this goal, various teaching and class management methods suitable for the Japanese educational environment, based on the theories of scholars such as Bandura (1977) and Zimmerman (1990), have been proposed by researchers including Yasunaga (2013). With the introduction of impactful governmental educational policies aimed at improving the quality of first-year education (Ministry of Education, Culture, Sports, Science and Technology, 2008; 2012), methods, classes, and programs to support self-regulated learning have now become popular in first-year education in Japan. Because self-regulated learners control their own actions and learning environment to find ways to succeed even in poor environments (Zimmerman, 1990), the progress in first-year education is expected to help students utilize university resources more effectively in order to accomplish their future goals.

However, the effectiveness of such classes and programs is not clear. In Japan, some studies have empirically shown that self-efficacy, which social cognitive theorists assumed was one of the key elements of self-regulated learning (Zimmerman, 1989), influences the academic outcomes of first-year students (Wada \& Yamamoto, 2014). Because self-efficacy is a person's belief in the probability that he or she will accomplish his or her goals using his or her individual skills in a given environment (Bandura, 1994), developing self-efficacy is an important element in motivating students to learn. Therefore, a more precise understanding of self-efficacy in first-year education could contribute significantly to improving the outcomes of university education. Although some empirical studies in self-efficacy have investigated the influence of specific teaching methods or academic subjects, such as mathematics, on self-efficacy (for example, see Yamada et al., 2010), no research so far has focused on first-year education.

This study attempts to examine the influence of a first-year class on students' self-efficacy. Because the analysis 
examines an actual class in daily practice, we cannot test the hypotheses in a controlled experimental environment. Instead, we evaluate the influence of the class by analyzing the class design from the perspective of the theory of self-efficacy. Classifying the linkage between theory and class activities allows us to see the class's resource allocation. Trends in resource allocation describe the features of the class, which indicate the effect of the class on students' self-efficacy. Pursuant to this analysis, we also examine the change in students' general self-efficacy scales during the course period.

The remainder of this paper is organized as follows: Section 2 presents an overview of the class; Section 3 analyzes the relationship between the theory and class activities; Section 4 compares the difference in students' self-efficacy before and after the course; and Section 5 discusses the results and presents the conclusions.

\section{Overview of the Class}

This paper analyzes the "Introduction to APU" course, a semester-long elective course offered twice a year (spring semester/fall semester) for first-year students at a university in Japan. One class, consisting of 30 students, is held each week for 15 weeks. Within the class, groups of five are formed for various group activities. A third- or fourth-year teaching assistant supports each group. An overview of each class is presented in Table A1 in the Appendix.

The primary objective of this course is to assist in forming attitudes that will prepare students for all aspects of university life and to develop students' abilities to utilize various academic and nonacademic university resources, such as peer leader activities and multicultural events, to achieve their future goals. Thus, the class is designed to enhance students' skills as self-regulated learners, specifically focusing on the acquisition of active learning and problem-solving skills, and encouraging students to develop their ability to work toward future goals and maintain a high level of motivation for learning (Shin, 2013).

In order to improve students' chances of academic success, the class was designed to develop their self-efficacy, in accordance with the claims of social cognitive theorists that self-efficacy is a key variable affecting self-regulated learning (Zimmerman, 1989). Two main theories were applied to fulfill this objective while designing the course.

The first theory was developed by Bandura (1977), who claimed that four factors (i.e., enactive mastery experiences, vicarious experiences, social persuasion experiences, and experiences involving somatic and emotional states) affect self-efficacy. To address this theory, the class implemented various activities designed to introduce students to these types of experiences, which were expected to help the students develop self-efficacy.

Second, the class took into account the cooperative-learning theory proposed by Johnson et al. (1993). To increase opportunities for students to encounter the four types of experiences noted by Bandura (1994), the class was designed to use cooperative learning experiences. These basic elements (i.e., reciprocal interdependence; face-to-face interaction; individual and group accountability; interpersonal and small-group skills; and group processing, including reflection and points of improvement) were intended to create a favorable environment in which students' experiences would develop their self-efficacy.

\section{Course Design Analysis}

\subsection{Method}

Self-efficacy is classified into task-specific self-efficacy and general self-efficacy. Task-specific self-efficacy refers to a person's belief in the possibility of accomplishing a specific task or behavior, whereas general self-efficacy refers to an individual's perception of his or her ability to perform across a variety of different situations (Judge et al., 1998). Mainly focused on task-specific self-efficacy, Bandura (1977) claimed that four factors (i.e., enactive mastery experiences, vicarious experiences, social persuasion experiences, and experiences involving somatic and emotional states) affect self-efficacy. On the other hand, although task-specific self-efficacy is viewed as one of the key elements influencing general self-efficacy, no widely accepted theory has been proposed about the mechanism that influences general self-efficacy.

Based on this view, this study attempted to examine the resource allocation of the first-year course, specifically looking at its promotion of task-specific self-efficacy, to find those features of the course designed to develop students' self-efficacy. For the analysis, we evaluated each activity from two perspectives. One examines the factors that Bandura (1977) claimed to affect self-efficacy. The other perspective examines the features of tasks to be accomplished during the activities. 
The key elements of the activities intended to develop students' self-efficacy are as follows. Bandura (1994) stated that enactive mastery experiences involve overcoming obstacles through perseverance. To create a process through which students can engage in such experiences, the course must implement activities that include elements that could make each student experience positive progress. At the same time, a true enactive mastery experience must also involve activities containing elements to make students realize their limitations or experience difficulties. In the remainder of this paper, we call these experiences success and failure, respectively. The effective combination of both activities is expected to provide students with an enactive mastery experience.

On the topic of vicarious experiences, Bandura (1994) claimed that observing people similar to oneself achieving success through sustained effort could also develop self-efficacy. Therefore, a key element of the activities to make students encounter vicarious experiences is the provision of an opportunity to share the experiences of others.

Regarding social persuasion, Bandura (1994) stated that people who are persuaded verbally that they possess the capability to master a given activity are likely to make a greater effort to succeed. Therefore, a key element in an activity to create this experience involves other people providing positive persuasion or advice to students.

Physiological (somatic and emotional) states, as defined by Bandura (1994), were not included in the course analysis. Although each activity in the course was not explicitly intended to enhance students' physiological (somatic and emotional) states, this course nevertheless introduced two schemes in its basic course design to accomplish this objective. First, cooperative learning, which underpinned all the activities in the learning scheme, was intended to improve students' physiological (somatic and emotional) states as the course progressed. Second, the course introduced interviews and advice from the senior teaching assistant as it progressed. One of the objectives of the support from the teaching assistant is to enhance students' physiological state.

When considering tasks to be accomplished, the activities can be classified according to two features. One is the goal of the task that the activity means for students to accomplish. The other is the degree and the type of influence exerted to affect task-specific self-efficacy. The combination of these features indicates the influence of the activities on a certain task-specific self-efficacy measure.

Based on this idea, this study classified each activity from the viewpoint of the four factors proposed by Bandura (1977), and also categorized activities using a task-related viewpoint. Classifying the activities to examine the course's resource allocation allows us to see the features of the course design, thereby inferring the effect of the course on students' self-efficacy.

\subsection{Result and Discussion}

Table 1-1, Table 1-2, and Table 1-3 present the course activities that were intended to help students undergo enactive mastery experiences (Table 1-1), vicarious experiences (Table 1-2), and social persuasion experiences (Table 1-3). The details of the activities are listed in Table A2 in the Appendix.

This course required students to accomplish three tasks as a way to fully encounter enactive mastery experiences. One of the tasks was meant to help students acquire skills in time management. In this course, training was offered not only during the class, but also outside the class in the form of homework. A notable feature of the class is that, unlike an ordinary class, the teaching assistants advise students regarding time management in order to meet their due dates. Another task involved acquiring basic skills for learning at the university. The teaching assistants also play an important role in this objective outside the class by assisting students in completing assignments. The final task was to acquire basic skills for success. Although this goal could be too general to be categorized as a task, we included it in the analysis to fully show the features of the course.

To accomplish the assigned tasks, students are expected to experience both failure and success. One way to ensure this process is make students engage in similar activities repeatedly in pursuit of a goal, during which they will repeatedly experience both failure and success, although not according to some specific timing. Experiencing failures and successes during continuous work is an important step in learning to overcome obstacles. Furthermore, the objective is more likely to be accomplished with adequate support from others, helping to develop students' collaboration skills while also engaging them in an enactive mastery experience. In this paper, we call such activities "repeated activity."

When facilitating the task of acquiring basic skills for success, the process of engaging in an enactive mastery experience could involve a combination of non-repeated activities. We will call each of those activities a "one-time activity." Major features of a one-time activity are that the activity is completed within a class session and that each activity is intended to make students experience failure or success. Therefore, unlike repeated activities, the process of overcoming obstacles in this context could be created with an intended sequence of failure and success. 
The task of each activity in the realm of vicarious experiences is the experience that the activity intends students to observe. This implies that most vicarious experience activities are the same as those of the enactive mastery experiences. They differ in that the activities regarding vicarious experiences are meant for students to share or observe the experiences of others in the class with respect to in-class or in-course activities. In this course, those activities are related to enactive mastery experiences.

Two elements may affect activities' influence on the development of self-efficacy. One element is the person who went through the experience. This course provides the opportunity for students to share the experiences of other groups as well as the experiences of their own group members. The other element involves the characteristics of the experience that students observe. The characteristics are categorized based on two criteria. One is the result of the experience. The results of any experience can be positioned somewhere on a spectrum between success and failure. The other criterion is the amount of effort expended during the experience. Combining these two characteristics expresses the feature of the experience's influence on others. Watching someone succeed after exerting some effort influences observers more positively. In contrast, success without effort and failure without effort seem to negatively affect the self-efficacy of the experience's observer.

Table 1-1. Class Design for Developing Self-Efficacy

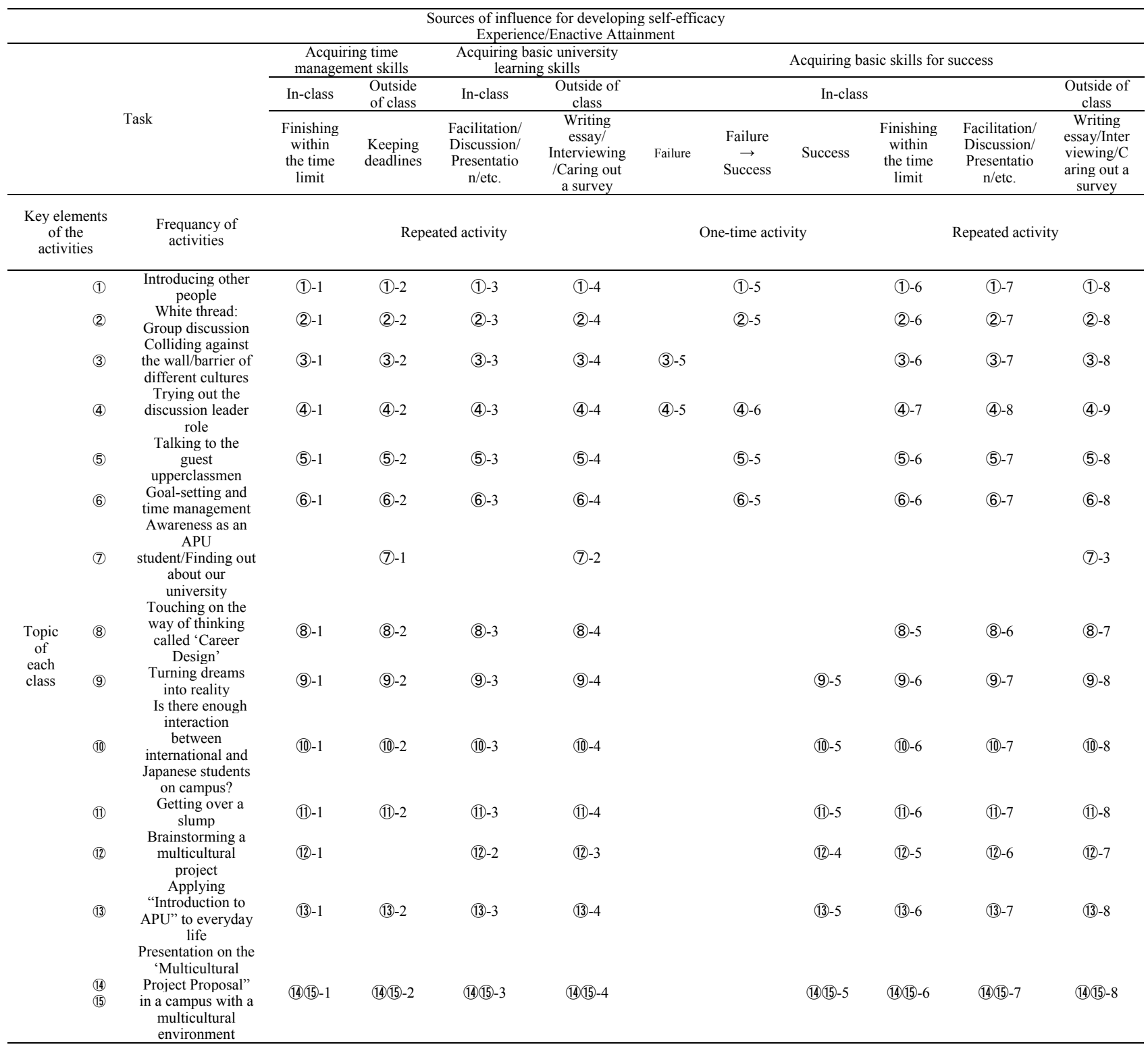


Table 1-2. Class Design for Developing Self-Efficacy

Sources of influence for developing self-efficacy

Modeling/Vicarious Experience

Task

Acquiring time management skills/Acquiring basic skills for success

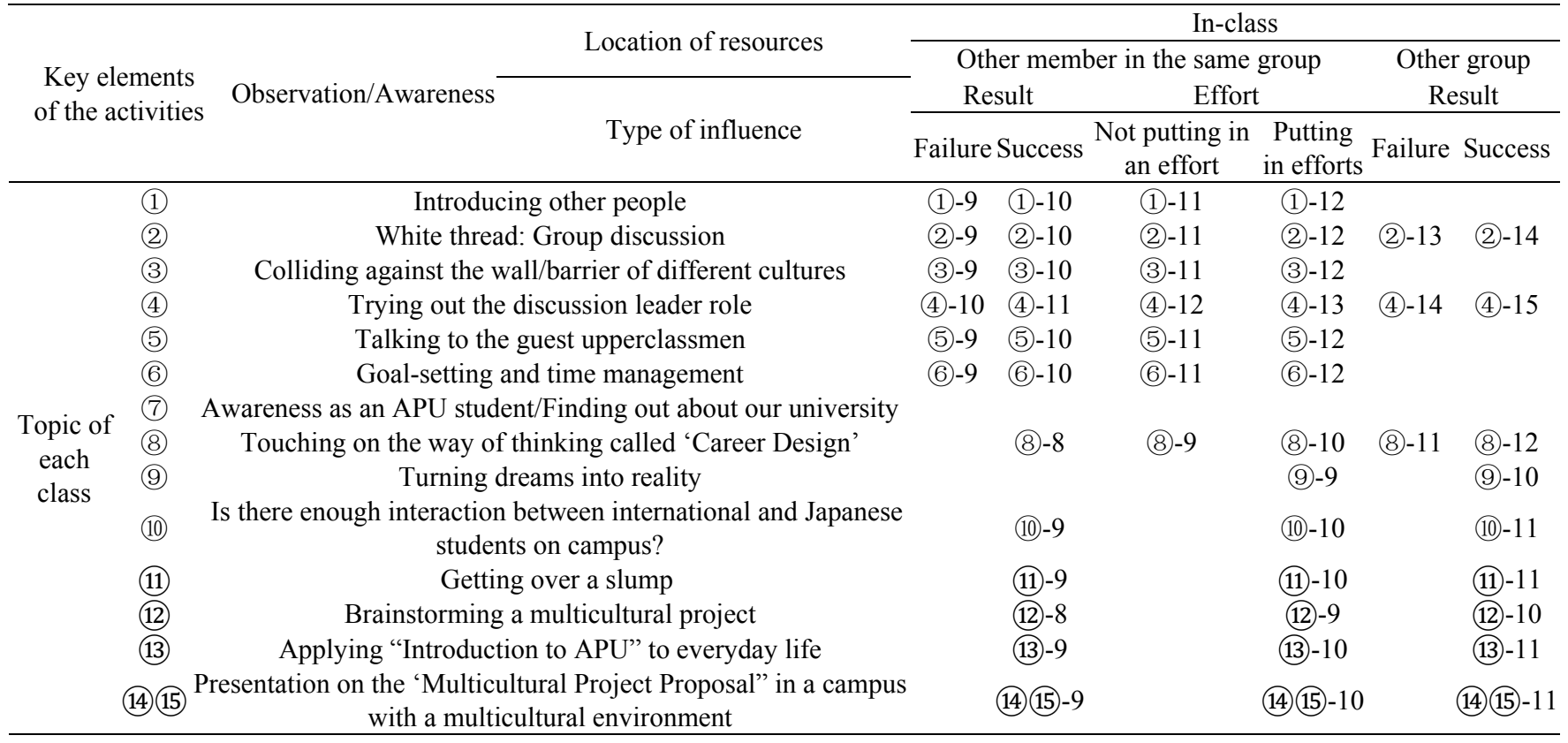

Table 1-3. Class Design Developing Self-Efficacy

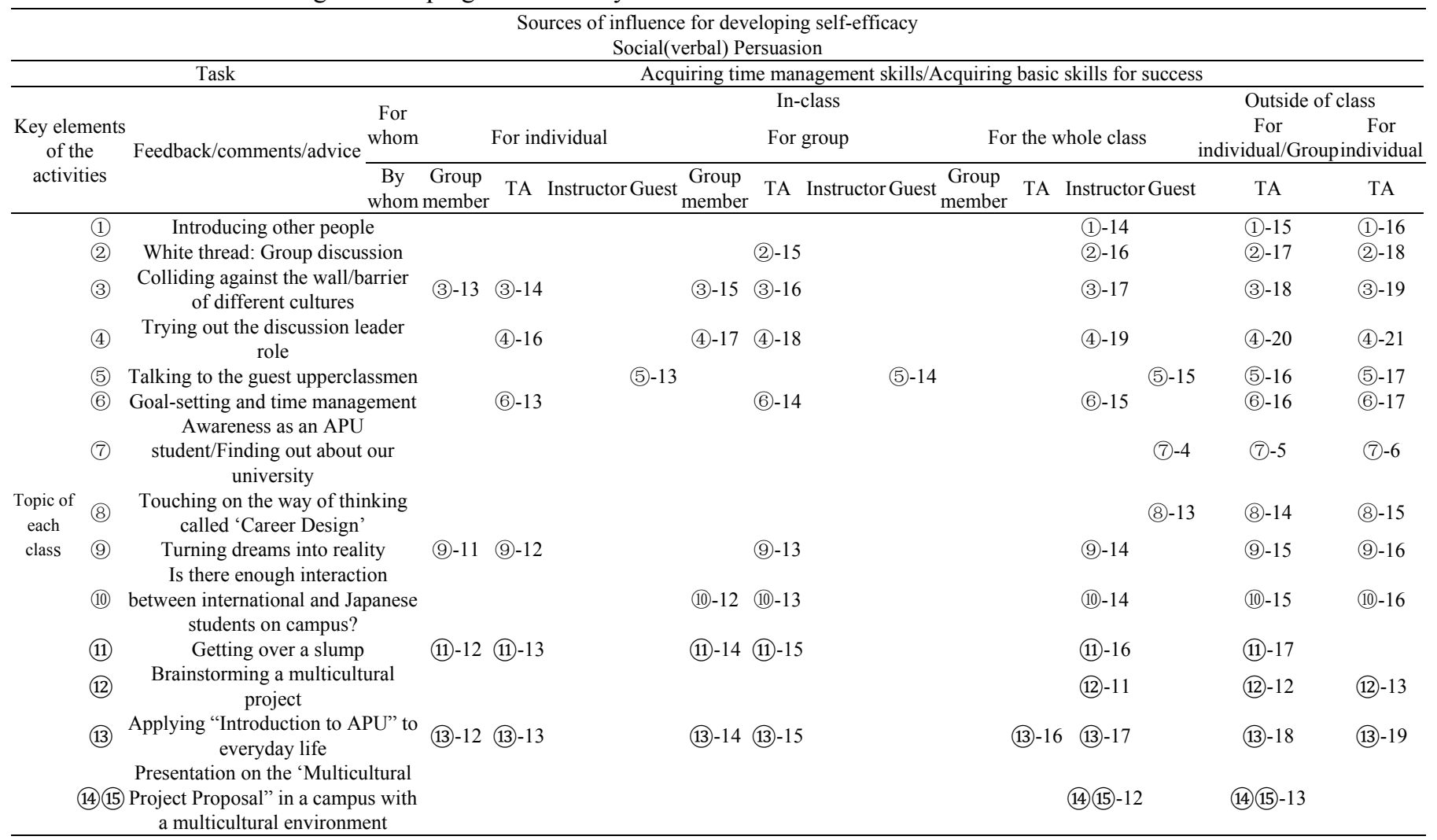


As for social persuasion, the activity tasks match the intension of the persuasion. The impact of the persuasion is affected by the target of the persuasion, the characteristics of the people who do the persuading, and the form of the persuasion. In this course, some persuasive discussions are targeted at individual students. Some additional persuasive speeches are made to groups or to the entire class. We categorized the types of persuaders into four groups. The first is classmates, and particularly a student's own group members. Second is the teaching assistant who assists with group work for each group. Third is the course's lecturer, and the fourth category comprises other individuals affiliated with the university. Additionally, the form of the persuasion can be classified into three categories: in-class opportunity, outside opportunity, or teaching assistant or lecturer's feedback on student assignments and homework. Unlike the other opportunities, this third category includes non-verbal persuasion such as writing.

Examining the combination of activities in the course reveals a number of intriguing features. Several characteristics are related to the enactive mastery experience (Table 1-1). First, repeated activities intended to accomplish two objectives (i.e., acquire time management skills and acquire basic university learning skills) are implemented in almost every class session. These types of training are implemented outside the session as well as in class. Second, examining the pattern of the one-time activities reveals a feature of the course designed to make students acquire basic skills for success. The course is intended to make students experience failure or a combination of failure and success in the early part of the course. In the latter part of the course, the activities are intended to help students to experience a continuous sense of success.

As for the activities regarding vicarious experiences (Table 1-2), the analysis revealed several tendencies. This course aims to utilize vicarious experiences as a mechanism to create a synergy effect helping students improve their efficacy by utilizing the experiences of their classmates regarding the enactive mastery experience. In particular, the activities regarding the tasks intended to help acquire basic skills for success and the vicarious experiences show a consistent pattern. The earlier part of the course provides students with opportunities to share both positive and negative experiences. In contrast, the latter part of the course is designed so that students share only experiences that are favorable for developing self-efficacy.

Examining the activities involving social persuasion (Table 1-3) revealed still more characteristics of the course. First, the most beneficial form of persuasion - persuasion directly targeted at an individual — had a particularly effective persuader: the teaching assistant. Notably, teaching assistants engaged in both in-class and out-of-class persuasion, and also non-verbal persuasion such as writing in addition to verbal persuasion. Second, an examination of the details of the persuasion activities (see Table 2A in the Appendix) makes it apparent that the teaching assistants primarily engage in persuasion based on the activities targeted at the enactive mastery experience. It implies that the major intention of the social persuasion in this class is to support the enactive mastery experience. Therefore, we may conclude that the major task of the activities regarding social persuasion is the same as that of the enactive mastery experience. Third, the lecturer gave advice to the whole class, but not to individual students or the small groups; this was effective, but in a different way than direct advice. Fourth, the course was designed to allow group members to frequently offer advice to each other.

After evaluating the activities from the perspective of enactive mastery experiences, vicarious experiences, and social persuasion experiences, we may understand the basic structure of the course. This course primarily intends to put students through an enactive mastery experience to develop their self-efficacy. The mechanism of social persuasion is used to strengthen the effect of that enactive mastery experience; it also complements the process by advising students to overcome obstacles to achieve success. The course also makes intensive use of cooperative learning to act as a mechanism for vicarious experience. By sharing the enactive mastery experiences of their classmates, students trigger a synergy effect designed by the course's creators.If the course has a positive impact on students' self-efficacy, any such development should have observable results related to the enactive mastery experience it provides. Because this course introduced repeated activities intended to help students acquire time management skills, basic university learning skills, and basic skills for success, some aspect of self-efficacy related to these areas can be expected to improve, presuming the course functioned as it was designed.

\section{Data Analysis}

\subsection{Method}

In this section, we examine the change in students' self-efficacy during the course period. Our study analyzes data collected from Japanese students participating in the 2012 spring semester course (April to July). Because Japanese universities begin their terms in April, this class is one of the first taken by new university students. Two classes were offered during the semester, and data was collected from both. Among the 60 total students enrolled in the course, 57 
students were Japanese citizens who had grown up in Japan and three were foreign students who lived outside Japan before university and did not speak Japanese as a native language. A survey was conducted twice during the course. The first survey was conducted during the first class session to evaluate students' self-efficacy before taking the course. The second survey was taken at the end of the last class session to evaluate students' self-efficacy after taking the course.

This study used the self-efficacy scale adopted by Narita et al. (1995), presented in Table 2 . The study selected 23 items from the general self-efficacy scale of Sherer et al. (1982) to examine the validity of the scale for a Japanese population. Our survey used the scale translated into Japanese by Narita et al. (1995), but the scale items presented in this paper are shown in English as presented by Sherer et al. (1982). Unlike either Sherer et al. (1982) or Narita et al. (1995), however, our study used a four-point scale instead of a five-point scale. We adopted this four-point scale because Japanese tend not to express their opinion (Joho shisutemu to shakai kankyo kenkyukai, 2012). Using a five-point scale might lead Japanese respondents to choose "not applicable" instead of their true opinion. Reverse items are indicated with (R). For the reverse items, reverse scores are presented in the Table 2.

The last row presents the sum of all scales as item (total). Narita et al. (1995) claimed that the self-efficacy scale for Japanese consists of a single factor, unlike the claim of Sherer et al. (1982) that it consists of two factors, a general self-efficacy scale and a social self-efficacy scale. For reference, we use $(\mathrm{G})$ to indicate items referring to the general self-efficacy factor, and (S) for items referring to the social self-efficacy factor, as distinguished by Sherer et al. (1982)

\subsection{Results and Discussion}

This study analyzed data from Japanese students. Thirteen samples were excluded from the analysis due to missing data. In Table 2, column 1 presents the sample median of each self-efficacy scale item before students took the course. Column 2 shows the sample of median of each self-efficacy scale item after completing the course. Only item (1), "When I make plans, I am certain I can make them work," showed a difference in median. However, average values were higher after the course for all items on the scale except item (10), "If I meet someone interesting who is hard to make friends with, I'll soon stop trying to make friends with that person,"and item (19), "I feel insecure about my ability to do things."

The Wilcoxon signed-rank test was conducted to examine the differences before and after taking the course. The p-values of the test statistics are presented in column 3. Among the items, only item (1), "When I make plans, I am certain I can make them work" $(\mathrm{p}=0)$, is statistically higher after the class than before at the $1 \%$ significance level. In addition, item (1) is the only item for which the median of the samples is higher after taking the class than before.

Examining the items by statistical significance at the $10 \%$ level (two-tail test), we see that several items show a higher scale after the course than before: item (1) "When I make plans, I am certain I can make them work" $(p=0)$; item (3), "If I can't do a job the first time, I keep trying until I can" ( $\mathrm{p}=.051)$; item (7), "If I see someone I would like to meet, I go to that person instead of waiting for him or her to come to me" ( $p=.068)$; item (8), "I avoid facing difficulties" ( $\mathrm{p}=.034)$; and item (20), "I am a self-reliant person" $(\mathrm{p}=.05)$. A statistically significant increase was also revealed in item (total), the sum of all scores $(\mathrm{p}=.002)$ after taking the course.

The general self-efficacy scale proposed by Sherer et al. (1982) measures willingness to initiate behavior, willingness to expend effort in completing the behavior, and persistence in the face of adversity. Examining the items whose values increased during the course period from this perspective, it is likely that improvement was made in all areas, but primarily in willingness to initiate behavior.

Sherer et al. (1982) also distinguished between a general self-efficacy factor and a social self-efficacy factor. Evaluating the items that increased during the course period from this perspective, it is likely that improvement was made to both factors, but relatively more so to general self-efficacy. 
Table 2. Score of the General Self-Efficacy Scale

\begin{tabular}{|c|c|c|c|c|}
\hline & \multirow[t]{2}{*}{ Items } & \multicolumn{2}{|c|}{ Median } & \multirow{2}{*}{$\begin{array}{l}\text { Wilcoxon } \\
\text { signed-rank test } \\
\text { p-value }\end{array}$} \\
\hline & & \multicolumn{2}{|c|}{ before after } & \\
\hline (1) & G When I make plans, I am certain I can make them work & 2 & 3 & 0 \\
\hline$(2)$ & G One of my problems is that I cannot get down to work when I should. & 2 & 2 & 0.379 \\
\hline (3) & G If I can't do a job the first time. I keep trying until I can. & 3 & 3 & 0.051 \\
\hline (4) & $\mathrm{S}$ It is difficult for me to make new friends. & 3 & 3 & 0.767 \\
\hline$(5)$ & R G When I set important goals for myself, I rarely achieve them. & 3 & 3 & 0.445 \\
\hline (6) & $\mathrm{R}$ G I give up on things before completing them. & 3 & 3 & 0.217 \\
\hline (7) & S If I see someone I would like to meet, I go to that person instead of waiting for him or her to come to me. & 3 & 3 & 0.068 \\
\hline (8) & R G I avoid facing difficulties. & 2 & 3 & 0.034 \\
\hline (9) & R G If something looks too complicated, I will not even bother to try it. & 2 & 2 & 0.133 \\
\hline (10) & $\mathrm{S}$ If I meet someone interesting who is hard to make friends with. 1'11 soon stop trying to make friends with that person. & 3 & 3 & 0.28 \\
\hline (11) & G When I have something unpleasant to do, I stick to it until I finish it. & 3 & 3 & 0.67 \\
\hline (12) & G When I decide to do something, I go right to work on it. & 3 & 3 & 0.079 \\
\hline (13) & R G When trying to learn something new, I soon give up if I am not initially successful. & 3 & 3 & 0.686 \\
\hline (14) & S When I'm trying to become friends with someone who seems uninterested at first, I don't give up easily. & 3 & 3 & 0.131 \\
\hline$(15)$ & R G When unexpected problems occur, I don't handle them well. & 3 & 3 & 0.353 \\
\hline (16) & R G I avoid trying to learn new things when they look too difficult for me. & 3 & 3 & 0.246 \\
\hline (17) & G Failure just makes me try harder. & 3 & 3 & 0.11 \\
\hline (18) & R S I do not handle myself well in social gatherings. & 3 & 3 & 0.592 \\
\hline (19) & R G I feel insecure about my ability to do things. & 2 & 2 & 0.175 \\
\hline$(20)$ & G I am a self-reliant person. & 2 & 3 & 0.05 \\
\hline$(21)$ & S I have acquired my friends through my personal abilities at making friends. & 3 & 3 & 0.52 \\
\hline$(22)$ & R G I give up easily. & 3 & 3 & 0.637 \\
\hline$(23)$ & R G I do not seem capable of dealing with most problems that come up in life. & 3 & 3 & 0.224 \\
\hline \multirow[t]{4}{*}{ (total) } & & 60.5 & 62.5 & 0.002 \\
\hline & $\mathrm{R}$ : reverse items & & & \\
\hline & G: general self-efficacy factor (by Sherer et al. (1982)) & & & \\
\hline & S: social self-efficacy factor (by Sherer et al. (1982)) & & & \\
\hline
\end{tabular}

\section{General Discussion}

This study examined the effect of a first-year class in developing the self-efficacy of university students in Japan. First, an analysis was conducted to classify the relationship between class activities and the theory proposed by Bandura (1977), examining the course features. The analysis indicates that the course was primarily intended improve students' self-efficacy by putting them through enactive mastery experiences. Notably, the course used intensive cooperative learning as a vicarious experience mechanism to trigger a synergy effect regarding the enactive mastery experience. In addition, this course used the social persuasion mechanism to strength the effects of students' enactive mastery experiences. Further, the mechanism is utilized to help students undergo experiences to overcome obstacles.

Statistical analysis has shown that the students developed some of the measures on the general self-efficacy scales during the course period. Several key tendencies were observed upon closer examination. First, significant improvement was observed on the item, "When I make plans, I am certain I can make them work." This item is closely linked to the activities related to the task of time management. Time management is one of the tasks that the course was actively intended to develop through various activities. Therefore, it is possible that this feature of the class design was reflected in the course's result, namely, an improvement in students' task-specific self-efficacy regarding time management. Second, in general, it is likely that general self-efficacy improved during the course period.

Because the statistical analysis was conducted only with a group actively enrolled in the course (that is, a "treatment" group as opposed to a "control" group), the analysis only indicates that students' self-efficacy improved during the course period; we cannot conclude that the class itself led to the improvement in students' self-efficacy. However, the results do imply the possibility that the class has positively influenced the students' self-efficacy. Future research can explore identification of the causality, such as through evaluating the effect under a more ideal experimental research setting, and analysis of the detailed mechanism of the class. 


\section{References}

Bandura, A. (1977). Self-efficacy: Toward a unifying theory of behavioral change. Psychological Review, 84, 19-215. http://dx.doi.org/10.1037/0033-295X.84.2.191

Bandura, A. (1994). Self-efficacy. In V.S. Ramachaudran (Ed.), Encyclopedia of human behavior (Vol. 4, pp. 71-81). New York: Academic Press.

Johnson, D.W., Johnson, R.T., \& Holubec, E.J. (1993). Circles of learning, cooperation in the classroom, Minneapolis, MN: Interaction Book Company.

Joho shisutemu to shakai kankyo kenkyukai (2012). Joho shisutemu no yukosei hyoka: Ryoteki hyoka no gaidorain [Method to evaluate information systems]. Retrieved from http://ipsj-is.jp/w/wp-content/uploads/2013/03/40840f0863a6eee5948ae7db61d2d6ee.pdf

Judge, T. A., Erez, A., \& Bono, J. A. (1998). The power of being positive: The relation between positive self-concept and job performance. Human Performance, 11, 167-187. http://dx.doi.org/10.1080/08959285.1998.9668030

Kawashima, K. (2008). Shonennji kyouiku no hirogari to gakushi kyouiku [Role of first-year education in university education)]paper presented in Dai-27-kai kyouiku kenkyuu koukai sinpojiumu (NIEPR, the 27th Symposium for Education). Ministry of Education, Culture, Sports, Science and Technology, Tokyo, Japan.

Ministry of Education, Culture, Sports, Science and Technology (MEXT) (2008). Gakushi katei kyouiku no kouchiku ni mukete [Reform in university education]. Retrieved from http://www.mext.go.jp/component/b_menu/shingi/toushin/_icsFiles/afieldfile/2013/05/13/1212958_001.pdf

Ministry of Education, Culture, Sports, Science and Technology (MEXT) (2012). Aratana mirai wo kizuku tame no daigakukyouiku no shistuteki tennkan ni mukete [Quality improvement of university education for the future]. Retrieved from http://www.mext.go.jp/component/b_menu/shingi/toushin/_icsFiles/afieldfile/2012/10/04/1325048_1.pdf

Narita, K., Shimonaka, J., Nakazato, K., Kawai, C., Sato, S., \& Osada, Y. (1995). Tokuseiteki-jiko-koryokukan shakudo no kentou [A Japanese version of the generalized self-efficacy scale: Scale utility from the life-span perspective]. Kyoiku Shinrigaku Kenkyuu, 43(3), 306-314. http://dx.doi.org/10.5926/jjep1953.43.3_306

Sherer, M., Maddux, J. E., Mercandante, B., Prentice-Dunn, S., Jacobs, B., \& Rogers, R.W. (1982). The self-efficacy scale: Construction and validation. Psychological Reports, 51, 663-671. http://dx.doi.org/10.2466/pr0.1982.51.2.663

Shin, K. (2013). Daigaku deno manabi no tameno taido-keisei wo mezashita jugyo-dukuri kyoro-gakushu deno shikake to kufuu [Creating a class with aim of attitude formation for studies at university: Approaches and method of cooperative learning]. Shakai Sisutemu Kenkyuu, 26(1), 119-135.

Yamada, M., Kitamura, S, Misono. T., \& Yamauchi, U. (2010). Komyunikeishon wo tuujita eigo-gakushuu ni okeru gakushuu-sha no gakugyou-teki jiko-gainen to jiko-kouryokukan no henyou [Effect of communication in English learning on self-concept and self-efficacy], paper presented in Dai-26-kai nihon kyoiku kougakkai (the 26th annual conference of Japan Society for Educational Technology), Kinjo Gakuin University, Nagoya, Japan. Retrieved from http://fukutake.iii.u-tokyo.ac.jp/archives/beat/projects/beat_conomi5.pdf

Yamada, R. (2013). Nihon ni okeru shonennji-kyoiku no doko: Kako genzai soshite mirai [Trends in first-year education in Japan: Past, present, and future]. In Shonenji Kyoiku Gakkai, Shonenji kyoiku no genjo to mirai [First-year experience: Current status and future prospects] (pp. 11-27), Tokyo, Japan: Sekai Shisosha. http://dx.doi.org/10.1589/rika.29.473

Yasunaga, S. (2012). Katsudosei wo takameru jugyo zukuri: Kyodo gakushu no susume [Creating a class design for enhancing the active learning process: Encouraging cooperative learning in the classroom]. Tokyo, Japan: Igaku Shoin.

Yasunaga, S. (2013). Kyodo-gakushu: Jugyo zukuri no kiso riron [Cooperative learning: The basic theory of class design). In Shonenji Kyoiku Gakkai, Shonenji kyoiku no genjo to mirai [First-year experience: Current status and future prospects] (pp.69-81), Tokyo, Japan: Sekai Shisosha.

Wada, T., \& Yamamoto, H. (2014). Jiko-koryokukan to seiseki no kankei [The relationship between self-efficacy and performance]. Rigakuryoho Kagaku, 29(4), 473-477.

Zimmerman, B. J. (1989). Social cognitive view of self-regulated academic learning. Journal of Educational 
Psychology, 81(3), 622-663. http://dx.doi.org/10.1037/0022-0663.81.3.329

Zimmerman, B. J. (1990). Self-regulated learning and academic achievement: An overview. Educational Psychologist, 25(1), 3-17. http://dx.doi.org/10.1207/s15326985ep2501_2

\section{Appendix}

\section{Table A1}

Class topic and activities

\begin{tabular}{|c|c|c|}
\hline \multicolumn{2}{|c|}{ Class topic } & \multirow{2}{*}{$\begin{array}{l}\text { Activities } \\
\text { Listening to others with a spirit of curiosity }\end{array}$} \\
\hline (1) & Introducing other people & \\
\hline (2) & White thread: Group discussion & Proactively expressing one's own opinions \\
\hline (3) & $\begin{array}{l}\text { Colliding against the wall/barrier of different } \\
\text { cultures }\end{array}$ & $\begin{array}{l}\text { Experiencing intercultural/multicultural collaborative/cooperative learning through interacting } \\
\text { with the English-basis class }\end{array}$ \\
\hline (4) & Trying out the discussion leader role & Taking on the roles of both discussion leader and member during the group discussions \\
\hline (5) & Talking to the guest upperclassmen & $\begin{array}{l}\text { Listening to the upperclassmen's stories, and then having a conversation about how to make the } \\
\text { best of university life as a freshman }\end{array}$ \\
\hline (6) & Goal-setting and time management & Analysing the record of one week's activities \\
\hline (7) & $\begin{array}{l}\text { Awareness as an APU student, learning about our } \\
\text { Alma Mater }\end{array}$ & Attending the First University President's special lecture \\
\hline (8) & $\begin{array}{l}\text { Touching on the way of thinking called 'Career } \\
\text { Design' }\end{array}$ & Attending the Career Office's special lecture \\
\hline (9) & Turning dreams into reality & Doing a peer consultation with a partner and outlining specific goals to fulfil one's own drams \\
\hline (10) & $\begin{array}{l}\text { Is there enough interaction between international } \\
\text { and Japanese students on campus? }\end{array}$ & $\begin{array}{l}\text { While learning in a multicultural environment, analyze the fact that interaction is limited, } \\
\text { brainstorm possible reasons/causes and propose solutions }\end{array}$ \\
\hline (11) & Getting over a slump & Noticing whether one has experienced any slumps and thinking of ways to overcome them \\
\hline (12) & Brainstorming a multicultural project & $\begin{array}{l}\text { Starting a project in mixed groups of English-basis and Japanese-basis students/Overcoming the } \\
\text { language barriers }\end{array}$ \\
\hline (13) & Applying "Introduction to APU" to everyday life & $\begin{array}{l}\text { Reflecting on what has been learnt and taken note of throughout the semester, and how to apply } \\
\text { these lessons to university life }\end{array}$ \\
\hline (14) (15) & $\begin{array}{l}\text { Presentation on the 'Multicultural Project } \\
\text { Proposal" in a campus with a multicultural } \\
\text { environment }\end{array}$ & Presenting a project collaboratively made in multicultural groups \\
\hline
\end{tabular}




\section{Table A2}

\section{Sources ofinfluencefor developing self-efficacy}

Experience/Enactive Attainment

Acquiring time management skills

\begin{tabular}{|c|c|c|c|}
\hline & & In-class & \\
\hline & & Finishin & hin the time limit \\
\hline & & Repeate & vity \\
\hline (1) & Introducing other people & (1) -1 & $\begin{array}{l}\text { Finishing the activity within the } \\
\text { time limit }\end{array}$ \\
\hline (2) & $\begin{array}{l}\text { White thread: Group } \\
\text { discussion }\end{array}$ & (2) -1 & $\begin{array}{l}\text { Finishing the activity within the } \\
\text { time limit }\end{array}$ \\
\hline (3) & $\begin{array}{l}\text { Colliding against the } \\
\text { wall/barrier of different } \\
\text { cultures }\end{array}$ & (3) -1 & $\begin{array}{l}\text { Finishing the activity within the } \\
\text { time limit }\end{array}$ \\
\hline (4) & $\begin{array}{l}\text { Trying out the discussion } \\
\text { leader role }\end{array}$ & (4) -1 & $\begin{array}{l}\text { Finishing the activity within the } \\
\text { time limit }\end{array}$ \\
\hline (5) & $\begin{array}{l}\text { Talking to the guest } \\
\text { upperclassmen }\end{array}$ & (5) -1 & $\begin{array}{l}\text { Finishing the activity within the } \\
\text { time limit }\end{array}$ \\
\hline (6) & $\begin{array}{l}\text { Goal-setting and time } \\
\text { management }\end{array}$ & (6) -1 & $\begin{array}{l}\text { Finishing the activity within the } \\
\text { time limit }\end{array}$ \\
\hline (8) & $\begin{array}{l}\text { Touching on the way of } \\
\text { thinking called 'Career } \\
\text { Design' }\end{array}$ & (8) -1 & $\begin{array}{l}\text { Finishing the activity within the } \\
\text { time limit }\end{array}$ \\
\hline (9) & Turning dreams into reality & (9) -1 & $\begin{array}{l}\text { Finishing the activity within the } \\
\text { time limit }\end{array}$ \\
\hline (10) & $\begin{array}{l}\text { Is there enough interaction } \\
\text { between international and } \\
\text { Japanese students on } \\
\text { campus? }\end{array}$ & (10) -1 & $\begin{array}{l}\text { Finishing the activity within the } \\
\text { time limit }\end{array}$ \\
\hline (11) & Getting over a slump & (11) -1 & $\begin{array}{l}\text { Finishing the activity within the } \\
\text { time limit }\end{array}$ \\
\hline (12) & $\begin{array}{l}\text { Brainstorming a } \\
\text { multicultural project }\end{array}$ & (12) -1 & $\begin{array}{l}\text { Finishing the activity within the } \\
\text { time limit }\end{array}$ \\
\hline (13) & $\begin{array}{l}\text { Applying "Introduction to } \\
\text { APU" to everyday life }\end{array}$ & (13) -1 & $\begin{array}{l}\text { Finishing the activity within the } \\
\text { time limit }\end{array}$ \\
\hline & Presentation on the & & \\
\hline (14) & $\begin{array}{l}\text { 'Multicultural Project } \\
\text { Proposal" in a campus with }\end{array}$ & (14)(15) -1 & $\begin{array}{l}\text { Finishing the activity within the } \\
\text { time limit }\end{array}$ \\
\hline
\end{tabular}

\section{Acquiring time management skills}

$\begin{array}{lll}\text { Outside of class } \\ \text { Keeping deadlines } \\ \text { (1) Introducing other people } & \text { (1) }-2 & \begin{array}{l}\text { Submit assignments until the } \\ \text { deadline } \\ \text { (2) White thread: Group }\end{array} \\ \begin{array}{lll}\text { (3) } \text { wall/barrier of different } & \text { (2) }-2 & \begin{array}{l}\text { Submit assignments until the } \\ \text { deadline }\end{array} \\ \text { (4) Trying out the discussion } & \text { (4) }-2 & \begin{array}{l}\text { Submit assignments until the } \\ \text { deadline }\end{array} \\ \text { (5) Tubmit assignments until the } \\ \text { deadline } \\ \text { ualking to the guest }\end{array} & \text { (5) }-2 & \begin{array}{l}\text { Submit assignments until the } \\ \text { deadline } \\ \text { Submit assignments until the } \\ \text { (6) Goadline }\end{array}\end{array}$

Awareness as an APU

(7) student/Finding out about

our university

Touching on the way of

(8) thinking called 'Career

Design'

(9) Turning dreams into reality

Is there enough interaction

(10) between international and

Japanese students on

campus?

(11) Getting over a slump

(13) Applying "Introduction to APU" to everyday life

Presentation on the

(14) "Multicultural Project

(15) Proposal" in a campus with a multicultural environment

\section{Acquiring basic university learning skills}

In-class

Facilitation/Discussion/Presentation/etc.

Repeated activity

\begin{tabular}{|c|c|c|c|}
\hline (1) & Introducing other people & (1) -3 & $\begin{array}{l}\text { Raising one's hand and reciting } \\
\text { one's observations }\end{array}$ \\
\hline & $\begin{array}{l}\text { White thread: Group } \\
\text { discussion }\end{array}$ & (2) -3 & $\begin{array}{l}\text { Raising one's hand and reciting } \\
\text { one's observations }\end{array}$ \\
\hline & $\begin{array}{l}\text { Colliding against the } \\
\text { wall/barrier of different } \\
\text { cultures }\end{array}$ & (3) -3 & $\begin{array}{l}\text { Presenting summaries of group } \\
\text { discussions }\end{array}$ \\
\hline & $\begin{array}{l}\text { Trying out the discussion } \\
\text { leader role }\end{array}$ & (4) -3 & $\begin{array}{l}\text { Using the } \mathrm{KJ} \text { method to hold } \\
\text { group discussions/presenting } \\
\text { summaries of group discussions }\end{array}$ \\
\hline & $\begin{array}{l}\text { Talking to the guest } \\
\text { upperclassmen }\end{array}$ & (5) -3 & $\begin{array}{l}\text { Showing interest and asking about } \\
\text { upperclassmen's experiences }\end{array}$ \\
\hline & $\begin{array}{l}\text { Goal-setting and time } \\
\text { management }\end{array}$ & (6) -3 & $\begin{array}{l}\text { Having reflective discussions } \\
\text { within the group }\end{array}$ \\
\hline & $\begin{array}{l}\text { Touching on the way of } \\
\text { thinking called 'Career } \\
\text { Design' }\end{array}$ & (8) -3 & $\begin{array}{l}\text { Using the } \mathrm{KJ} \text { method to hold } \\
\text { group discussions/presenting } \\
\text { summaries of group discussions }\end{array}$ \\
\hline & Turning dreams into reality & (9) -3 & $\begin{array}{l}\text { Having reflective discussions } \\
\text { within the group }\end{array}$ \\
\hline & $\begin{array}{l}\text { Is there enough interaction } \\
\text { between international and } \\
\text { Japanese students on } \\
\text { campus? }\end{array}$ & (10) -3 & $\begin{array}{l}\text { Discussing in the } \\
\text { group/presenting summaries of } \\
\text { group discussions }\end{array}$ \\
\hline & Getting over a slump & (11) -3 & $\begin{array}{l}\text { Using the } \mathrm{KJ} \text { method to hold } \\
\text { group discussions/presenting } \\
\text { summaries of group discussions }\end{array}$ \\
\hline & $\begin{array}{l}\text { Brainstorming a } \\
\text { multicultural project }\end{array}$ & (12) -2 & $\begin{array}{l}\text { New group formations of } \\
\text { international students with } \\
\text { Japanese students/Discussing in } \\
\text { Japanese and English/Presenting } \\
\text { summaries of group discussions in } \\
\text { both Japanese and English }\end{array}$ \\
\hline & $\begin{array}{l}\text { Applying "Introduction to } \\
\text { APU" to everyday life }\end{array}$ & (13) -3 & $\begin{array}{l}\text { Using the } \mathrm{KJ} \text { method to hold } \\
\text { group discussions/presenting } \\
\text { summaries of group discussions }\end{array}$ \\
\hline & $\begin{array}{l}\text { Presentation on the } \\
\text { "Multicultural Project } \\
\text { Proposal" in a campus with } \\
\text { a multicultural environment }\end{array}$ & 3 & $\begin{array}{l}\text { Cooperating with the international } \\
\text { student group }\end{array}$ \\
\hline
\end{tabular}

Acquiring basic university learning skills 


\begin{tabular}{|c|c|c|c|}
\hline & & \multicolumn{2}{|c|}{$\begin{array}{l}\text { Outside of class } \\
\text { Writing essay/Interviewing/Caring out a } \\
\text { survey } \\
\text { Repeated activity }\end{array}$} \\
\hline (1) & Introducing other people & (1) -4 & $\begin{array}{l}\text { Listening with interest to the other } \\
\text { person, proactively listening and } \\
\text { creating topics }\end{array}$ \\
\hline (2) & $\begin{array}{l}\text { White thread: Group } \\
\text { discussion }\end{array}$ & (2) -4 & $\begin{array}{l}\text { Writing a reflective essay on what } \\
\text { was learned this class }\end{array}$ \\
\hline (3) & $\begin{array}{l}\text { Colliding against the } \\
\text { wall/barrier of different } \\
\text { cultures }\end{array}$ & (3) -4 & $\begin{array}{l}\text { Writing a reflective essay on what } \\
\text { was learned this class }\end{array}$ \\
\hline (4) & $\begin{array}{l}\text { Trying out the discussion } \\
\text { leader role }\end{array}$ & (4) -4 & $\begin{array}{l}\text { Writing a reflective essay on what } \\
\text { was learned this class }\end{array}$ \\
\hline (5) & $\begin{array}{l}\text { Talking to the guest } \\
\text { upperclassmen }\end{array}$ & (5) -4 & $\begin{array}{l}\text { Interviewing an upperclassman } \\
\text { outside of class and making a } \\
\text { report about it/writing a reflective } \\
\text { essay on what was learned this } \\
\text { class }\end{array}$ \\
\hline (6) & $\begin{array}{l}\text { Goal-setting and time } \\
\text { management }\end{array}$ & (6) -4 & $\begin{array}{l}\text { Writing a reflective essay on what } \\
\text { was learned this class/creating a } \\
\text { one-week schedule } \\
\text { chart/recording its implementation }\end{array}$ \\
\hline (7) & $\begin{array}{l}\text { Awareness as an APU } \\
\text { student/Finding out about } \\
\text { our university }\end{array}$ & (7) -2 & $\begin{array}{l}\text { Writing a reflective essay on what } \\
\text { was learned this class }\end{array}$ \\
\hline (8) & $\begin{array}{l}\text { Touching on the way of } \\
\text { thinking called 'Career } \\
\text { Design' }\end{array}$ & (8) -4 & $\begin{array}{l}\text { Writing a reflective essay on what } \\
\text { was learned this class }\end{array}$ \\
\hline (9) & Turning dreams into reality & (9) -4 & $\begin{array}{l}\text { Making smaller objectives, } \\
\text { carrying them out and writing a } \\
\text { report/Listening to others and } \\
\text { carrying out interviews with the } \\
\text { proactive stance and curiosity } \\
\text { learned until this point }\end{array}$ \\
\hline (10) & $\begin{array}{l}\text { Is there enough interaction } \\
\text { between international and } \\
\text { Japanese students on } \\
\text { campus? }\end{array}$ & (10) -4 & $\begin{array}{l}\text { Writing a reflective essay on what } \\
\text { was learned this class }\end{array}$ \\
\hline (11) & Getting over a slump & (11) -4 & $\begin{array}{l}\text { Creating a poster on } 10 \text { ways to } \\
\text { overcome a slump }\end{array}$ \\
\hline (12) & $\begin{array}{l}\text { Brainstorming a } \\
\text { multicultural project }\end{array}$ & (12) -3 & $\begin{array}{l}\text { Talk to international students } \\
\text { outside of class and start creating } \\
\text { the project proposal }\end{array}$ \\
\hline (13) & $\begin{array}{l}\text { Applying "Introduction to } \\
\text { APU" to everyday life }\end{array}$ & (13) -4 & $\begin{array}{l}\text { Using what was discussed within } \\
\text { the group as a basis, reflect on } \\
\text { what was learned during this } \\
\text { course as a whole and write an } \\
\text { essay on how to fully utilize it }\end{array}$ \\
\hline $\begin{array}{l}\text { (14) } \\
\text { (15) }\end{array}$ & $\begin{array}{l}\text { Presentation on the } \\
\text { 'Multicultural Project } \\
\text { Proposal" in a campus with } \\
\text { a multicultural environment }\end{array}$ & (14) (15) -4 & $\begin{array}{l}\text { Write about experiences in } \\
\text { university life as case } \\
\text { studies/write a reflective essay } \\
\text { regarding the TA }\end{array}$ \\
\hline
\end{tabular}

\section{Acquiring basic skills for success}

In-class

Failure

One-time activity

Colliding against the

(3) wall/barrier of different cultures

\footnotetext{
Mixing the Japanese-basis class and the English-basis class into groups for discussion (Unable to communicate with words due to the language barrier/first-time experience)
}

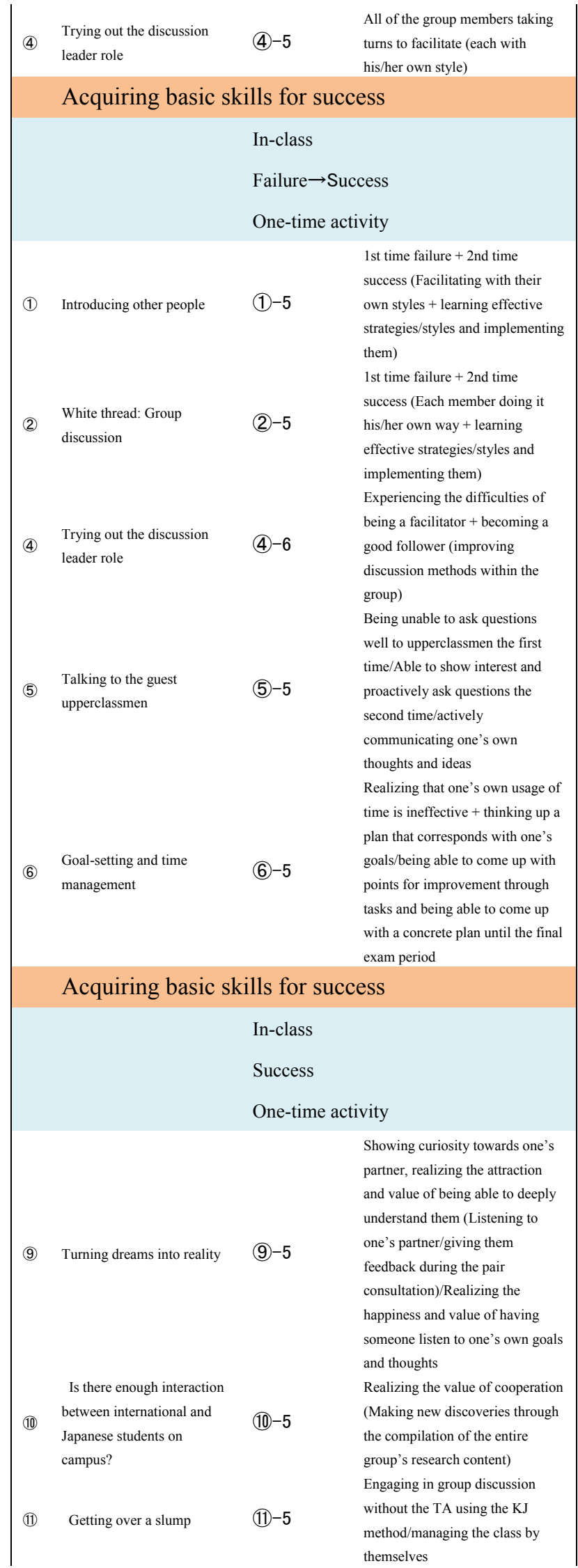




\begin{tabular}{|c|c|c|c|}
\hline (12) & $\begin{array}{l}\text { Brainstorming a } \\
\text { multicultural project }\end{array}$ & (12) -4 & $\begin{array}{l}\text { Having discussions with } \\
\text { international students/They were } \\
\text { completely unable to discuss } \\
\text { during the } 3 \text { rd class, but compared } \\
\text { to last time their level of } \\
\text { conversation has improved }\end{array}$ \\
\hline (13) & $\begin{array}{l}\text { Applying "Introduction to } \\
\text { APU" to everyday life }\end{array}$ & (13) -5 & $\begin{array}{l}\text { Their discussion is the most } \\
\text { productive out of all the ones they } \\
\text { have had/Their presentation } \\
\text { content and skills also improve }\end{array}$ \\
\hline $\begin{array}{l}\text { (14) } \\
\text { (15) }\end{array}$ & $\begin{array}{l}\text { Presentation on the } \\
\text { 'Multicultural Project } \\
\text { Proposal" in a campus with } \\
\text { a multicultural environment }\end{array}$ & (14)(15) -5 & $\begin{array}{l}\text { They present their project } \\
\text { proposal in the large classroom as } \\
\text { a mixed group with the } \\
\text { international students }\end{array}$ \\
\hline
\end{tabular}

\section{Acquiring basic skills for success}

In-class

Finishing within the time limit

Repeated activity

(1) Introducing other people

(1) -6

Submit assignments until the

White thread: Group

discussion

(2) -6

Colliding against the

(3) wall/barrier of different

cultures

Trying out the discussion

leader role

Talking to the guest

upperclassmen

Goal-setting and time

management

Touching on the way of

(8) thinking called 'Career

Design'

(9) Turning dreams into reality

Is there enough interaction

(11) between international and

Japanese students on

campus?$$
\text { (12) }
$$$$
\text { (12) }
$$

(13) Applying "Introduction to

APU" to everyday life

Presentation on the

(14) 'Multicultural Project

(15) Proposal" in a campus with a multicultural environmen

\section{Acquiring basic skills for success}

\begin{tabular}{|lll} 
In-class & \multicolumn{2}{l}{$\begin{array}{l}\text { Facilitation/Discussion/Presentation/etc. } \\
\text { Repeated activity }\end{array}$} \\
(1) Introducing other people & (1) -7 & $\begin{array}{l}\text { Raising one's hand and reciting } \\
\text { one's observations } \\
\text { Raising one's hand and reciting } \\
\text { one's observations }\end{array}$ \\
(3) $\begin{array}{l}\text { White thread: Group } \\
\text { discussion }\end{array}$ & (2) -7 & $\begin{array}{l}\text { Presenting summaries of group } \\
\text { wiscussions }\end{array}$
\end{tabular}

Submit assignments until the

deadline

(3) -6

Submit assignments until the

deadline

(4) -7

Submit assignments until the

deadline

(5) -6

Submit assignments until the

deadline

(6) -6

Submit assignments until the

deadline

(8)-5 Submit assignments until the

(9)-6 Submit assignments until the

deadline

(10) -6 Submit assignments until the

deadline

Submit assignments until the

deadline

Submit assignments until the

deadline

Submit assignments until the

deadline

Submit assignments until the

\section{(14) (15)-6 $\quad \begin{aligned} & \text { Submit ass } \\ & \text { deadline }\end{aligned}$}

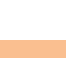

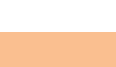

(4)

(4) leader role

(4) -8

Talking to the guest

upperclassmen

6. Goal-setting and time

management

Awareness as an APU

(8) student/Finding out about

our university

(9) Turning dreams into reality

Is there enough interaction

(10) between international and

(10) Japanese students on

campus?

(11) Getting over a slump 


\begin{tabular}{|c|c|c|}
\hline $\begin{array}{l}\text { Touching on the way of } \\
\text { thinking called 'Career } \\
\text { Design' }\end{array}$ & (8) -7 & $\begin{array}{l}\text { Writing a reflective essay on what } \\
\text { was learned this class }\end{array}$ \\
\hline Turning dreams into reality & (9) -8 & $\begin{array}{l}\text { Making smaller objectives, } \\
\text { carrying them out and writing a } \\
\text { report/Listening to others and } \\
\text { carrying out interviews with the } \\
\text { proactive stance and curiosity } \\
\text { learned until this point }\end{array}$ \\
\hline $\begin{array}{l}\text { Is there enough interaction } \\
\text { between international and } \\
\text { Japanese students on } \\
\text { campus? }\end{array}$ & (10) -8 & $\begin{array}{l}\text { Writing a reflective essay on what } \\
\text { was learned this class }\end{array}$ \\
\hline Getting over a slump & (11) -8 & $\begin{array}{l}\text { Creating a poster on } 10 \text { ways to } \\
\text { overcome a slump }\end{array}$ \\
\hline $\begin{array}{l}\text { Brainstorming a } \\
\text { multicultural project }\end{array}$ & (12) -7 & $\begin{array}{l}\text { Talk to international students } \\
\text { outside of class and start creating } \\
\text { the project proposal }\end{array}$ \\
\hline $\begin{array}{l}\text { Applying "Introduction to } \\
\text { APU" to everyday life }\end{array}$ & (13) -8 & $\begin{array}{l}\text { Using what was discussed within } \\
\text { the group as a basis, reflect on } \\
\text { what was learned during this } \\
\text { course as a whole and write an } \\
\text { essay on how to fully utilize it }\end{array}$ \\
\hline $\begin{array}{l}\text { Presentation on the } \\
\text { 'Multicultural Project } \\
\text { Proposal" in a campus with } \\
\text { a multicultural environment }\end{array}$ & (14) (15) -8 & $\begin{array}{l}\text { Write about experiences in } \\
\text { university life as case } \\
\text { studies/write a reflective essay } \\
\text { regarding the TA }\end{array}$ \\
\hline
\end{tabular}

\section{Modeling/Vicarious Experience} Acquiring time management skills/Acquiring basic skills for success

In-class

Other member in the same group

Result

Failure

\begin{tabular}{|c|c|c|}
\hline Introducing other people & (1) -9 & Not an attractive introduction \\
\hline $\begin{array}{l}\text { White thread: Group } \\
\text { discussion }\end{array}$ & (2) -9 & Hardly talks/talks too much \\
\hline $\begin{array}{l}\text { Colliding against the } \\
\text { wall/barrier of different } \\
\text { cultures }\end{array}$ & (3) -9 & Can't communicate with words \\
\hline $\begin{array}{l}\text { Trying out the discussion } \\
\text { leader role }\end{array}$ & (4) -10 & Can't facilitate well \\
\hline $\begin{array}{l}\text { Talking to the guest } \\
\text { upperclassmen }\end{array}$ & (5) -9 & $\begin{array}{l}\text { The upperclassmen are so } \\
\text { outstanding one feels he/she can't } \\
\text { be like them }\end{array}$ \\
\hline $\begin{array}{l}\text { Goal-setting and time } \\
\text { management }\end{array}$ & (6) -9 & $\begin{array}{l}\text { Realizing that the other members } \\
\text { are not good at time management }\end{array}$ \\
\hline
\end{tabular}
Acquiring time management skills/Acquiring basic skills for success

In-class

Other member in the same group

Result

Success

(1) Introducing other people (1)-10

$\begin{array}{ll}\text { (2) White thread: Group } & \text { (2) }-10\end{array}$

See members who are able to make interesting introductions See members who are able to fully participate in discussions

\begin{tabular}{|c|c|c|}
\hline (3) & $\begin{array}{l}\text { Colliding against the } \\
\text { wall/barrier of different } \\
\text { cultures }\end{array}$ & (3) -10 \\
\hline (4) & $\begin{array}{l}\text { Trying out the discussion } \\
\text { leader role }\end{array}$ & (4) -11 \\
\hline (5) & $\begin{array}{l}\text { Talking to the guest } \\
\text { upperclassmen }\end{array}$ & (5) -10 \\
\hline (6) & $\begin{array}{l}\text { Goal-setting and time } \\
\text { management }\end{array}$ & (6) -10 \\
\hline (8) & $\begin{array}{l}\text { Touching on the way of } \\
\text { thinking called 'Career } \\
\text { Design' }\end{array}$ & (8) -8 \\
\hline (10) & $\begin{array}{l}\text { Is there enough interaction } \\
\text { between international and } \\
\text { Japanese students on } \\
\text { campus? }\end{array}$ & (10) -9 \\
\hline (11) & Getting over a slump & (11) -9 \\
\hline & $\begin{array}{l}\text { Brainstorming a } \\
\text { multicultural project }\end{array}$ & -8 \\
\hline
\end{tabular}

Applying "Introduction to APU" to everyday life

(13) -9

Presentation on the

(14) 'Multicultural Project

(15) Proposal" in a campus with a multicultural environment

Acquiring time management skills/Acquiring basic skills for success

In-class

Other group

Effort

Not putting in an effort Too shy or embarrassed to

(1) Introducing other people

(1) -11 talk/talks softly/hard-to-understand explanations

White thread: Group discussion

(2) -11 Colliding against the

(3) wall/barrier of different cultures Wants to be more proactive but can't do it

Has given up on communicating with others

(4) Trying out the discussion

Close-minded, always sticking to leader role

Talking to the guest upperclassmen

See members who are good at (through body language, gestures) See other members who are good members who are good at the Learn about the experiences of overcoming the lively conditions accomplish/Learn the contributions of APU alumni to society/demonstrate assertivenes

See members who are good at

Watch each other's presentations nd see how the quality of nas gone up compa

See members who are good at Observe the improvement of the ernational students' Japanese members' English skill and see how the quality of to the content in the first few

ee how much effort the other roups put in/the quality of other groups' presentations/the level of teamwork )

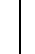




$\begin{array}{lll}\text { (6) Goal-setting and time } & \text { (6) }-11 & \text { Does his/her work haphazardly } \\ \text { management } & & \\ \text { Touching on the way of } & \text { (8) }-9 & \text { Sleeps in class }\end{array}$

Design' skills for success

In-class

Other group

Effort

Putting in effort

$\begin{array}{lll}\text { (1) Introducing other people } & \text { (1)-12 } & \begin{array}{l}\text { A lively introduction/Having } \\ \text { interest in one's partner }\end{array} \\ \text { (2) White thread: Group } & \text { (2) }-12 & \text { Trying out what was learned }\end{array}$

discussion

Colliding against the

(3) wall/barrier of different

cultures

3) -12 barrier/seeing members trying to

liven up the atmosphere even if

they don't understand one another

well

(4) Trying out the discussion leader role

(4) -13

Trying to do what he/she can by

him/herself

Being interested in one'

upperclassmen and listening to

5) Talking to the guest

upperclassmen

(5) -12

their stories/Empathizing with

them/Learning from the

upperclassmen

Learning how TAs manage their

6. Goal-setting and time

management

(6) -12

time well despite their busy

schedules

Listening while taking

(8) thinking called 'Career

Design'

(9) Turning dreams into reality

Is there enough interaction between international and Japanese students on campus?

(11) Getting over a slump

(11) -10

Getting wholeheartedly involved

Listening carefully to what the other wants to say/showing

interest in each other/Becoming able to empathize with the other Realizing that each member is actively participating in group work/realizing that they are enjoying themselves while doing so

Determining which groups

Presentation on the

(14) 'Multicultural Project

(15) Proposal" in a campus with a multicultural environment Acquiring time management skills/Acquiring basic skills for success

In-class

Other group

Result

\begin{tabular}{|c|c|c|c|}
\hline & & Failure & \\
\hline (2) & $\begin{array}{l}\text { White thread: Group } \\
\text { discussion }\end{array}$ & (2) -13 & $\begin{array}{l}\text { Seeing other groups' unorganized } \\
\text { presentations }\end{array}$ \\
\hline (4) & $\begin{array}{l}\text { Trying out the discussion } \\
\text { leader role }\end{array}$ & (4) -14 & $\begin{array}{l}\text { Seeing other groups not finish } \\
\text { their presentations within the } \\
\text { given time }\end{array}$ \\
\hline (8) & $\begin{array}{l}\text { Touching on the way of } \\
\text { thinking called 'Career } \\
\text { Design' }\end{array}$ & (8) -11 & $\begin{array}{l}\text { Seeing other groups not finish } \\
\text { their presentations within the } \\
\text { given time }\end{array}$ \\
\hline
\end{tabular}

Acquiring time management skills/Acquiring basic skills for success

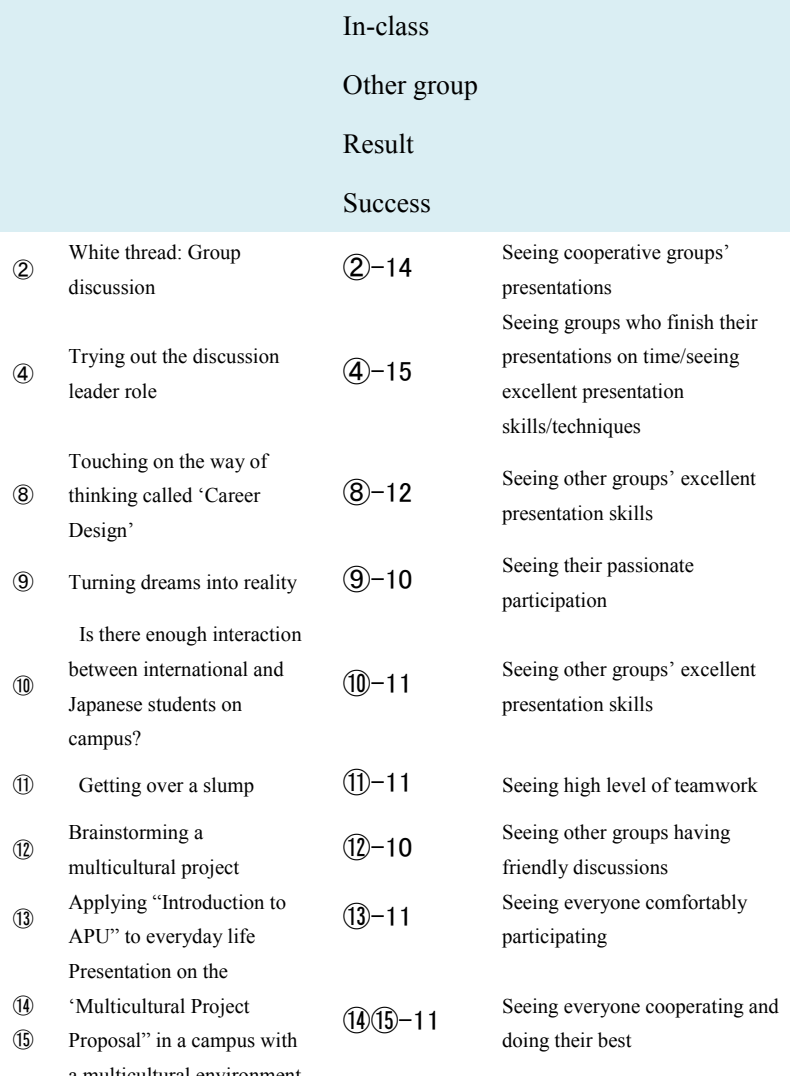

\section{Social (verbal) Persuasion}

Acquiring time management skills/Acquiring basic skills for success

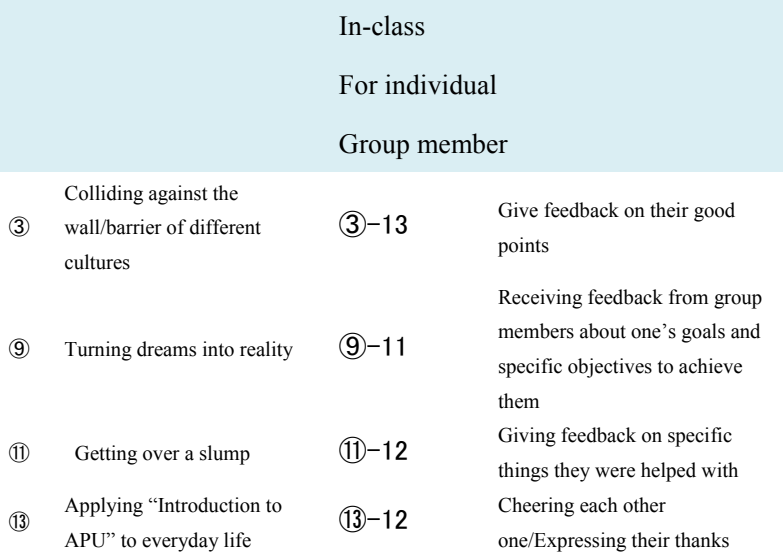




\begin{tabular}{|c|c|c|c|}
\hline & \multicolumn{3}{|c|}{$\begin{array}{l}\text { Acquiring time management skills/Acquiring basic } \\
\text { skills for success }\end{array}$} \\
\hline & \multicolumn{3}{|c|}{ In-class } \\
\hline & & \multicolumn{2}{|c|}{ For individual } \\
\hline & & \multicolumn{2}{|l|}{$\mathrm{TA}$} \\
\hline (3) & $\begin{array}{l}\text { Colliding against the } \\
\text { wall/barrier of different } \\
\text { cultures }\end{array}$ & (3) -14 & $\begin{array}{l}\text { Feedback from the TA (portray } \\
\text { what happened/what went well } \\
\text { and points for improvement) }\end{array}$ \\
\hline (4) & $\begin{array}{l}\text { Trying out the discussion } \\
\text { leader role }\end{array}$ & (4) -16 & $\begin{array}{l}\text { Feedback from the TA (what went } \\
\text { well and points for improvement) }\end{array}$ \\
\hline (6) & $\begin{array}{l}\text { Goal-setting and time } \\
\text { management }\end{array}$ & (6) -13 & $\begin{array}{l}\text { Feedback from the TA (what went } \\
\text { well and points for improvement) }\end{array}$ \\
\hline (9) & Turning dreams into reality & (9) -12 & $\begin{array}{l}\text { Feedback from the TA (what went } \\
\text { well and points for improvement) }\end{array}$ \\
\hline (11) & Getting over a slump & (11) -13 & $\begin{array}{l}\text { Feedback from the TA (what went } \\
\text { well and points for improvement) }\end{array}$ \\
\hline (13) & $\begin{array}{l}\text { Applying "Introduction to } \\
\text { APU" to everyday life }\end{array}$ & (13) -13 & $\begin{array}{l}\text { Feedback from the TA (what went } \\
\text { well and points for improvement) }\end{array}$ \\
\hline & \multicolumn{3}{|c|}{$\begin{array}{l}\text { Acquiring time management skills/Acquiring basic } \\
\text { skills for success }\end{array}$} \\
\hline & \multicolumn{3}{|c|}{ In-class } \\
\hline & & \multicolumn{2}{|c|}{ For individual } \\
\hline & & \multicolumn{2}{|c|}{ Instructor } \\
\hline \multicolumn{4}{|c|}{ (N/A) } \\
\hline & \multicolumn{3}{|c|}{$\begin{array}{l}\text { Acquiring time management skills/Acquiring basic } \\
\text { skills for success }\end{array}$} \\
\hline & \multicolumn{3}{|c|}{ In-class } \\
\hline & \multicolumn{3}{|c|}{ For individual } \\
\hline & & \multicolumn{2}{|l|}{ Guest } \\
\hline (5) & $\begin{array}{l}\text { Talking to the guest } \\
\text { upperclassmen }\end{array}$ & (5) -13 & $\begin{array}{l}\text { Communicate that there is } \\
\text { something each one can do }\end{array}$ \\
\hline & \multicolumn{3}{|c|}{$\begin{array}{l}\text { Acquiring time management skills/Acquiring basic } \\
\text { skills for success }\end{array}$} \\
\hline & \multicolumn{3}{|c|}{ In-class } \\
\hline & \multicolumn{3}{|c|}{ For group } \\
\hline & \multicolumn{3}{|c|}{ Group member } \\
\hline (3) & $\begin{array}{l}\text { Colliding against the } \\
\text { wall/barrier of different } \\
\text { cultures }\end{array}$ & (3) -15 & Share what was difficult \\
\hline (4) & $\begin{array}{l}\text { Trying out the discussion } \\
\text { leader role } \\
\text { Is there enough interaction }\end{array}$ & (4) -17 & $\begin{array}{l}\text { The importance of a follower's } \\
\text { attitude }\end{array}$ \\
\hline (10) & $\begin{array}{l}\text { between international and } \\
\text { Japanese students on } \\
\text { campus? }\end{array}$ & (10) -12 & $\begin{array}{l}\text { Communicate one's own } \\
\text { realizations }\end{array}$ \\
\hline (11) & Getting over a slump & (11) -14 & $\begin{array}{l}\text { Was able to cooperate well with } \\
\text { others }\end{array}$ \\
\hline (13) & $\begin{array}{l}\text { Applying "Introduction to } \\
\text { APU" to everyday life }\end{array}$ & (13) -14 & $\begin{array}{l}\text { Cheer each other on/Praise each } \\
\text { other }\end{array}$ \\
\hline & \multicolumn{3}{|c|}{$\begin{array}{l}\text { Acquiring time management skills/Acquiring basic } \\
\text { skills for success }\end{array}$} \\
\hline \multicolumn{4}{|c|}{ In-class } \\
\hline
\end{tabular}

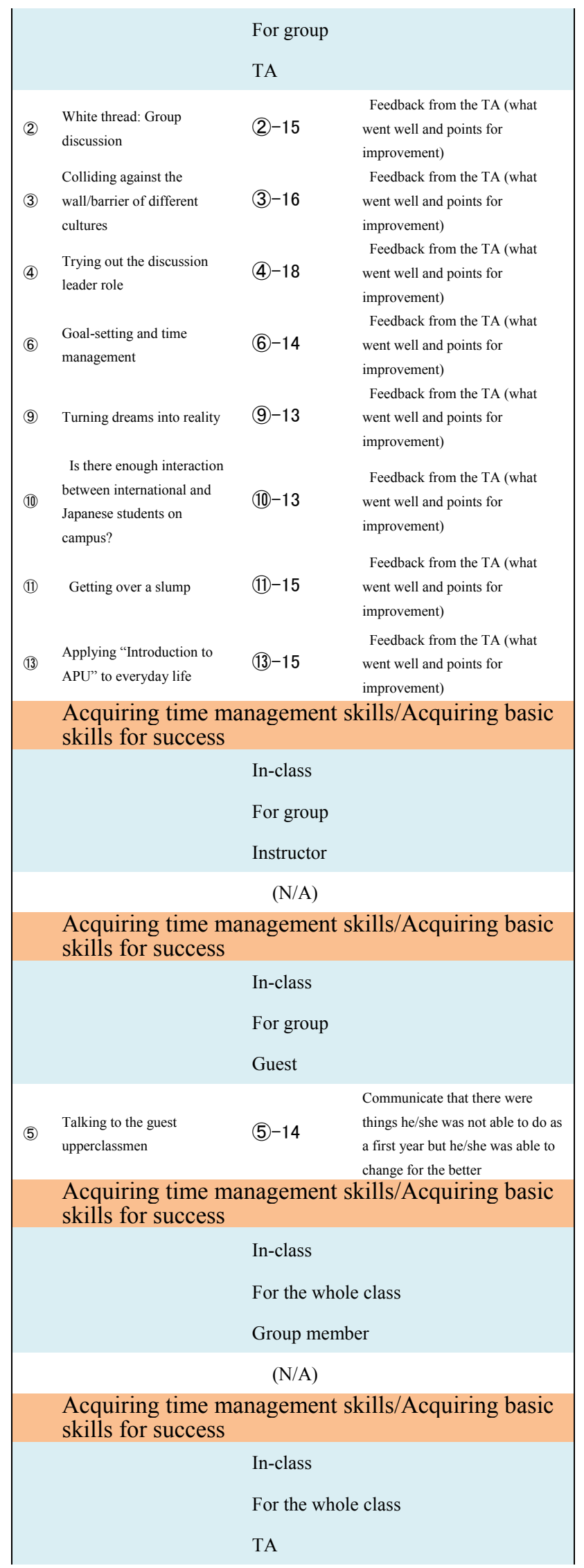




\begin{tabular}{|c|c|c|c|}
\hline (13) & $\begin{array}{l}\text { Applying "Introduction to } \\
\text { APU" to everyday life }\end{array}$ & (13) -16 & $\begin{array}{l}\text { Expectations for the students and } \\
\text { message of support }\end{array}$ \\
\hline & \multicolumn{3}{|c|}{$\begin{array}{l}\text { Acquiring time management skills/Acquiring basic } \\
\text { skills for success }\end{array}$} \\
\hline \multicolumn{4}{|c|}{ For the whole class } \\
\hline (1) & Introducing other people & (1) -14 & $\begin{array}{l}\text { The introductions of the second } \\
\text { batch of pairs has improved/The } \\
\text { change in facial expressions and } \\
\text { attitude brought about by their } \\
\text { interest }\end{array}$ \\
\hline (2) & $\begin{array}{l}\text { White thread: Group } \\
\text { discussion }\end{array}$ & (2) -16 & $\begin{array}{l}\text { The number of recitations during } \\
\text { the 2nd time increased from the } \\
\text { 1st time/the speakers' tangents are } \\
\text { also decreasing/communicating } \\
\text { the importance of conscious } \\
\text { participation }\end{array}$ \\
\hline (3) & $\begin{array}{l}\text { Colliding against the } \\
\text { wall/barrier of different } \\
\text { cultures }\end{array}$ & (3) -17 & $\begin{array}{l}\text { The difficulties faced from this } \\
\text { class will be of use later } \\
\text { on/communicate the value of } \\
\text { facing difficulties }\end{array}$ \\
\hline (4) & $\begin{array}{l}\text { Trying out the discussion } \\
\text { leader role }\end{array}$ & (4) -19 & $\begin{array}{l}\text { 1. Relay the importance of both } \\
\text { facilitator and follower roles/relay } \\
\text { the value of being able to act as a } \\
\text { facilitator }\end{array}$ \\
\hline (6) & $\begin{array}{l}\text { Goal-setting and time } \\
\text { management }\end{array}$ & (6) -15 & $\begin{array}{l}\text { Relay how translating it into } \\
\text { physical form heightened } \\
\text { awareness of time/relay the } \\
\text { importance of time management } \\
\text { and order of priorities }\end{array}$ \\
\hline (9) & Turning dreams into reality & (9) -14 & $\begin{array}{l}\text { Communicate the worth of one's } \\
\text { actions/communicate that each } \\
\text { person is valued }\end{array}$ \\
\hline (10) & $\begin{array}{l}\text { Is there enough interaction } \\
\text { between international and } \\
\text { Japanese students on } \\
\text { campus? }\end{array}$ & (10) -14 & $\begin{array}{l}\text { Communicate how the } \\
\text { organization of information leads } \\
\text { to new discoveries/Praise the } \\
\text { members' cooperation with one } \\
\text { another }\end{array}$ \\
\hline (11) & Getting over a slump & (11) -16 & $\begin{array}{l}\text { Commend the group members for } \\
\text { being able to manage the class by } \\
\text { themselves }\end{array}$ \\
\hline (12) & $\begin{array}{l}\text { Brainstorming a } \\
\text { multicultural project }\end{array}$ & (12) -11 & $\begin{array}{l}\text { Communicate the importance of } \\
\text { meetings outside of class }\end{array}$ \\
\hline (13) & $\begin{array}{l}\text { Applying "Introduction to } \\
\text { APU" to everyday life }\end{array}$ & (13) -17 & $\begin{array}{l}\text { Communicate how the students } \\
\text { should utilize what they have } \\
\text { learned afterwards and hone their } \\
\text { leadership skills }\end{array}$ \\
\hline $\begin{array}{l}\text { (14) } \\
\text { (15) }\end{array}$ & $\begin{array}{l}\text { Presentation on the } \\
\text { 'Multicultural Project } \\
\text { Proposal" in a campus with } \\
\text { a multicultural environment }\end{array}$ & (14) (15) -12 & Feedback for presentations \\
\hline & \multicolumn{3}{|c|}{$\begin{array}{l}\text { Acquiring time management skills/Acquiring basic } \\
\text { skills for success }\end{array}$} \\
\hline & & $\begin{array}{l}\text { In-class } \\
\text { For the } \\
\text { Guest }\end{array}$ & class \\
\hline (5) & $\begin{array}{l}\text { Talking to the guest } \\
\text { upperclassmen }\end{array}$ & (5) -15 & $\begin{array}{l}\text { Participate and state what was } \\
\text { learned from everyone in the } \\
\text { group }\end{array}$ \\
\hline
\end{tabular}

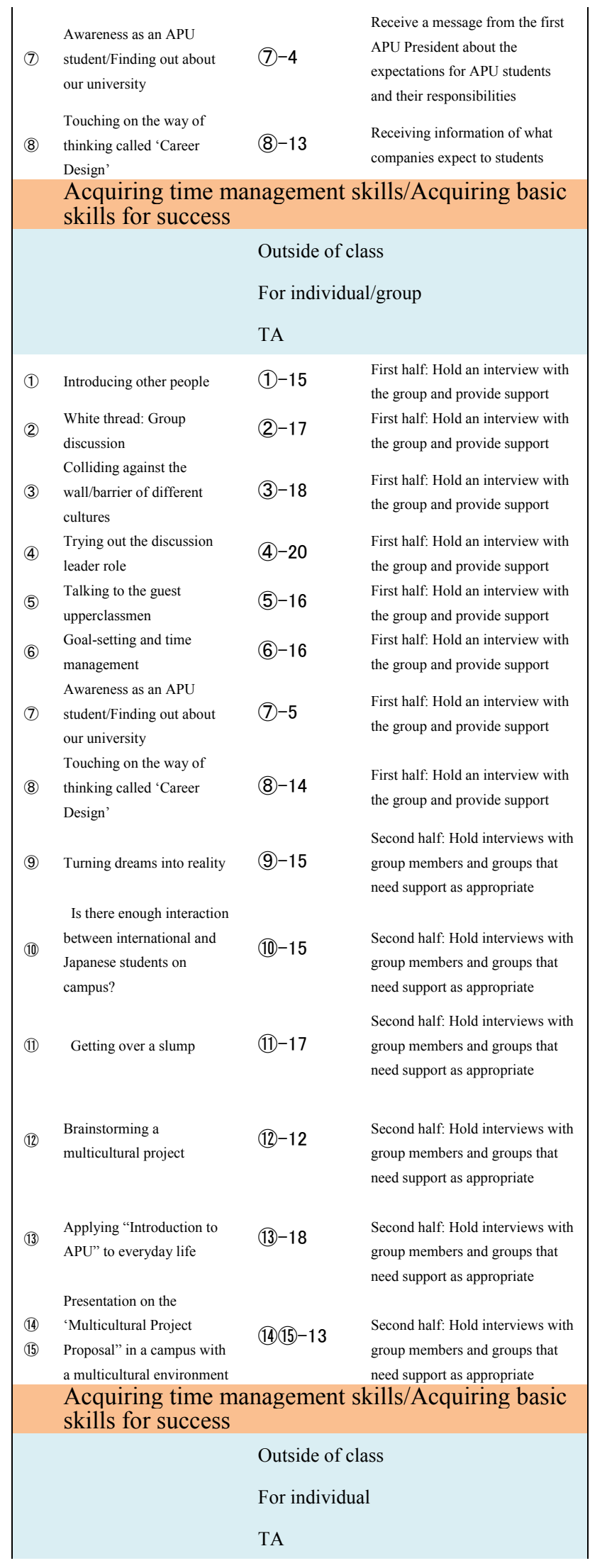




\begin{tabular}{|c|c|c|c|}
\hline (1) & Introducing other people & (1) -16 & $\begin{array}{l}\text { Feedback on the assignments } \\
\text { from the TA/Points that the } \\
\text { student is working hard on and } \\
\text { points that were admirable/things } \\
\text { noticed during class }\end{array}$ \\
\hline (2) & $\begin{array}{l}\text { White thread: Group } \\
\text { discussion }\end{array}$ & (2) -18 & $\begin{array}{l}\text { Feedback on the assignments } \\
\text { from the TA/Points that the } \\
\text { student is working hard on and } \\
\text { points that were admirable/things } \\
\text { noticed during class }\end{array}$ \\
\hline (3) & $\begin{array}{l}\text { Colliding against the } \\
\text { wall/barrier of different } \\
\text { cultures }\end{array}$ & (3) -19 & $\begin{array}{l}\text { Feedback on the assignments } \\
\text { from the TA/Points that the } \\
\text { student is working hard on and } \\
\text { points that were admirable/things } \\
\text { noticed during class }\end{array}$ \\
\hline (4) & $\begin{array}{l}\text { Trying out the discussion } \\
\text { leader role }\end{array}$ & (4) -21 & $\begin{array}{l}\text { Feedback on the assignments } \\
\text { from the TA/Points that the } \\
\text { student is working hard on and } \\
\text { points that were admirable/things } \\
\text { noticed during class }\end{array}$ \\
\hline (5) & $\begin{array}{l}\text { Talking to the guest } \\
\text { upperclassmen }\end{array}$ & (5) -17 & $\begin{array}{l}\text { Feedback on the assignments } \\
\text { from the TA/Points that the } \\
\text { student is working hard on and } \\
\text { points that were admirable/things } \\
\text { noticed during class }\end{array}$ \\
\hline (6) & $\begin{array}{l}\text { Goal-setting and time } \\
\text { management }\end{array}$ & (6) -17 & $\begin{array}{l}\text { Feedback on the assignments } \\
\text { from the TA/Points that the } \\
\text { student is working hard on and } \\
\text { points that were admirable/things } \\
\text { noticed during class }\end{array}$ \\
\hline (7) & $\begin{array}{l}\text { Awareness as an APU } \\
\text { student/Finding out about } \\
\text { our university }\end{array}$ & (7) -6 & $\begin{array}{l}\text { Feedback on the assignments } \\
\text { from the TA/Points that the } \\
\text { student is working hard on and } \\
\text { points that were admirable/things } \\
\text { noticed during class }\end{array}$ \\
\hline (8) & $\begin{array}{l}\text { Touching on the way of } \\
\text { thinking called 'Career } \\
\text { Design' }\end{array}$ & (8) -15 & $\begin{array}{l}\text { Feedback on the assignments } \\
\text { from the TA/Points that the } \\
\text { student is working hard on and } \\
\text { points that were admirable/things } \\
\text { noticed during class }\end{array}$ \\
\hline (9) & Turning dreams into reality & (9) -16 & $\begin{array}{l}\text { Feedback on the assignments } \\
\text { from the TA/Points that the } \\
\text { student is working hard on and } \\
\text { points that were admirable/things } \\
\text { noticed during class }\end{array}$ \\
\hline (10) & $\begin{array}{l}\text { Is there enough interaction } \\
\text { between international and } \\
\text { Japanese students on } \\
\text { campus? }\end{array}$ & (10) -16 & $\begin{array}{l}\text { Feedback on the assignments } \\
\text { from the TA/Points that the } \\
\text { student is working hard on and } \\
\text { points that were admirable/things } \\
\text { noticed during class }\end{array}$ \\
\hline (12) & $\begin{array}{l}\text { Brainstorming a } \\
\text { multicultural project }\end{array}$ & (12) -13 & $\begin{array}{l}\text { Feedback on the assignments } \\
\text { from the TA/Points that the } \\
\text { student is working hard on and } \\
\text { points that were admirable/things } \\
\text { noticed during class }\end{array}$ \\
\hline (13) & $\begin{array}{l}\text { Applying "Introduction to } \\
\text { APU" to everyday life }\end{array}$ & (13) -19 & $\begin{array}{l}\text { Feedback on the assignments } \\
\text { from the TA/Points that the } \\
\text { student is working hard on and } \\
\text { points that were admirable/things } \\
\text { noticed during class }\end{array}$ \\
\hline
\end{tabular}

